\title{
Enhancing Learners' Academic Performances Using Student Centered Approaches
}

\author{
$\underline{\text { https://doi.org/10.3991/ijet.v15i16.14875 }}$
}

\author{
Preeti Jaiswal ${ }^{\square}{ }^{\varpi}$, Abdulghani Ali Al-Hattami \\ University of Bahrain, Sakheer, Kingdom of Bahrain \\ pjaiswal@uob.edu.bh
}

\begin{abstract}
Contemporary higher education institutions place students at the centre of their thinking and emphasize on student centered approaches to help learners construct knowledge during their learning paths in higher education. The study was guided by Bloom's taxonomy in designing learning outcomes, incorporating engaging learning activities and assessing learning outcomes. Bloom's Taxonomy of Educational Objectives provides a hierarchical classification system that classifies thinking abilities from basic information acquisition to more complex processes. The purpose of this study was to examine the effects of using the hierarchical instructional set of cognitive processes delineated in Bloom's taxonomy for boosting learners' vocabulary competency in English language learning, in higher education. The sample for this study consisted of 39 students (nine males and thirty females) who were studying course entitled English for Business in Department of English Language \& Literature, College of Arts, during the academic year 2018-19 at University of Bahrain. The course aims to enhance learners' language skills to enable them to communicate constructively in various business contexts. The results revealed that Bloom's learning approach was successful in augmenting learners 'retention and transfer of productive and receptive vocabulary in language learning and conducive for promoting proficiency in English vocabulary knowledge.
\end{abstract}

Keywords-Cognitive Achievement, Bloom's taxonomy, autonomous learners, higher order thinking skills, productive and receptive vocabulary.

\section{Introduction}

Teaching within higher education has experienced a pedagogical shift in recent years, with new approaches to enhance student motivation, autonomy and achievement (Fernandes, Flores, and Lima, 2012). Student centered learning is a pedagogical approach that takes learning pace among students, and the differences between their learning styles, their interests, skills and needs into consideration. Also, the experiences of students, the content and structuring knowledge is significant in the studentcentered learning environments. Instructors prudently evolve a structured learning environment where students are provided support and guidance to accomplish skills in self-evaluation and independence in their learning (Klenowski, 1995). A student cen- 
tred approach encompasses four fundamental features: active engagement for learning, dedicated enthusiastic management of learning experience, autonomous knowledge construction and teachers in the role of facilitators (Geven and Santa, 2010). Collectively, they exemplify the process of active teaching in a self-directed learning environment (Grabinger and Dunlap, 1994). Here, students achieve more when instructors explain learning objectives explicitly and the students are made aware of what they are expected to achieve in that session (Rosenshine, 1983). The study was guided by Bloom's taxonomy in designing learning outcomes, incorporating engaging learning activities and assessing learning outcomes. Bloom's Taxonomy of Educational Objectives provides a hierarchical classification system and was constructed by an educational psychologist, Benjamin Bloom in 1956. It emphasizes on enhancing thinking ability which involves basic information acquisition to more complex processes (Bloom, 1956). The taxonomy delineates learning into three domains of educational activities: cognitive, affective and psychomotor. Each of the three domains further categorizes learning into five levels organized hierarchically from basic, surface level learning to complex, deeper level learning. The cognitive domain relates to the mind and intellectual abilities. It is the knowledge and thinking domain and is concerned with how humans gain, enhance, and apply knowledge. The affective domain is connected with human values, attitudes, and feeling. It is the emotional domain and handles students' new feelings or emotions that they evolve for a subject, and/or themselves. It focuses on how students build positive, responsible attitudes, motivation, and greater appreciation, and how they put more values on certain things during the learning process. The taxonomy for affective domain consists of a fiveleveled classification system consisting of receiving, responding, valuing, organizing and characterizing. The psychomotor domain, added later to Bloom's taxonomy, is connected with human actions, movements, coordination, and physical skills and is concerned with how humans use motor skills. The taxonomy for psychomotor domain consists of five hierarchically organized categories, comprising of imitating, manipulating, precision, articulating and naturalization. All the three taxonomies serve as objectives of the learning process and at the end of a learning session, students are expected to have attained new knowledge, new skills, and attitudes towards a subject. Educators may find Bloom's taxonomy useful in designing their course curriculum, describing students' intended learning outcomes lucidly, selecting relevant learning tasks, and assessing students' learning outcomes. This Taxonomy, furthermore, provides a list of measurable action verbs for each hierarchical level, to help educators describe and classify observable knowledge, skills, attitudes, behaviors and abilities. By formulating measurable student learning outcomes employing these measurable verbs, educators can distinctly indicate what learners must perform to demonstrate their learning at each particular level. The 2001 matrix organization is a revised version of Bloom's taxonomy and is handy and practical for educators as well as learners. It assists educators in creating clear learning objectives for lesson plans and evaluating students' performances to monitor their progress towards mastery of each domain of learning. Moreover, the hierarchical model, makes it simpler and easier for students to understand the learning targets they are expected to achieve by the end of a learning program. 


\section{$2 \quad$ Literature Review}

Research, policy and practice claiming to take a student-centered approach have continued to grow (Lea, Stephenson, and Troy, 2003). A student centred approach encompasses four fundamental features: active engagement for learning, dedicated enthusiastic management of learning experiences, autonomous knowledge construction and teachers in the role of facilitators (Geven and Santa, 2010; Attard et al., 2010; Maclellan, 2008). Collectively, they exemplify the process of active teaching in a selfdirected learning environment (Grabinger and Dunlap, 1994). Active learning activities are designed to embody constructivist teaching principles. Students construct knowledge and understanding by modifying and refining their current concepts and adding new concepts to what is already known. Put simply, student centred approaches motivate students to construct knowledge through real-life examples and relevant activities and require 'active' engagement to comprehend the new information: by selecting, deciphering and applying knowledge to everyday situations to resolve complicated vocational issues (Jacobson and Mark, 1995; Meyers and Jones, 1993; Silberman, 1996; Tenenbaum et al., 2001; White, 1996). Active learning (AL) is a method for engaging students in higher-order thinking tasks (e.g., analysis, evaluation, reflection, creation) through engaging learning activities so that students achieve more than being merely passive learners. In this context, the purpose of the study was to determine the effects of applying Bloom's taxonomy on academic achievement of students in vocabulary enhancement. Bloom's taxonomy of educational objectives has been an influential framework in the field of education. According to David. R. Krathwohl, Bloom's taxonomy, is a framework to classify statements of what educators expect their students to learn through the process of instruction (Krathwohl, 2002).The original taxonomy comprised of six levels: knowledge, comprehension, application, analysis, synthesis and evaluation (Bloom et al., 1956) with each having their own carefully developed definitions (Krathwohl, 2002). These categories were selected to reflect on the distinctions that educators were already forming among student behaviors (Bloom et al., 1956). All six levels were organized from the simple level eventually building to the higher complex level and question stems with measurable verbs encouraged thinking from concrete to abstract levels. Case (2013) said that Bloom's taxonomy "is seen to prescribe a necessary pathway for learning that requires moving up the hierarchy" (p. 4). In other words, students must master the first level before proceeding to the next one (Murphy \& O’Neill, 2010) In 1999, Dr. Lorin Anderson, a student of Bloom along with his colleagues published an updated version of Bloom's Taxonomy that takes into account a broader range of factors that influence the teaching and learning process. The revised taxonomy for cognitive domain is a six-leveled classification system consisting of remembering, understanding, applying, analyzing, evaluating and creating. Krathwohl (2002) claimed that the taxonomy represented a hierarchy, in that each category was seen as a prerequisite to the next. The first two levels provided the prerequisites for building the higher-level skills. By focusing on the process of learning, the abilities of individuals and the promotion of student involvement, deeper cognitive engagement can be achieved (Newble \& Can- 
non, 1995). The study attempts to answer the question: Does utilizing Bloom's taxonomy significantly enhance vocabulary knowledge?

\subsection{Applying bloom's revised taxonomy of cognitive objectives for effective learning}

The cognitive domain lies at the core of Bloom's taxonomy of Objectives (1956). Skills in the cognitive domain are connected with knowledge, comprehension, and critical thinking of a particular topic. In this learning taxonomy the cognitive skills are categorized into six hierarchically structured levels which grow in complexity with each level and cognitive achievement at each level depends on having accomplished the prerequisite knowledge and skills at lower levels. The lower-levels, deal with simple knowledge acquisition, through cognitive skills of remembering and understanding. They ascend systematically to abilities of applying the content material to new situations, drawing connections and making judgments about the values of ideas through higher-order cognitive skills of applying, analyzing, and evaluating. At the pinnacle of the framework, is the ability of creating a new structure through generating and producing ideas. This taxonomy, also, presents a list of action verbs, typically linked with each hierarchical level. These measurable action verbs clearly indicate to learners what they must accomplish at each level. Moreover, educators can use these measurable verbs in boosting students 'attainments of cognitive skills as they progress through each hierarchical level as well as in outlining clear and effective intended learning outcomes such as "On completion of this course, students should be able to..." followed by an appropriate measurable action verb defining the anticipated performance according to the cognitive level and ending with the object of the statement which indicates the desired knowledge, skills, and attitudes/values that learners should have acquired and are expected to demonstrate through their performance at the end of an academic program. By writing intended learning outcomes in this manner clearly articulate to students what they should be able to know, do, and value by the end of a course. For example, "On completion of this course, students should be able to apply, independently, a variety of strategies, to infer meanings of unfamiliar words and phrases using contextual clues." A goal of Bloom's Taxonomy is to motivate educators to focus on all three domains (cognitive, affective and psychomotor) creating a more holistic form of education. Furthermore, educators may find the action verbs useful in assigning test questions cues for eliciting student responses and assessing students' learning within each specific level by giving questions that either require students to recall facts, describe a process, apply knowledge, classify information, solve a problem, evaluate a theory, or create an alternative solution. In this sense, the list of measurable action verbs assists educators in gauging students' cognitive achievement. The following six tables outline a successful method of using the six levels of cognitive learning according to the revised version of Bloom's Taxonomy to encourage higher order thinking skills and to promote a constructive alignment of intended learning objectives, active learning activities and assessment tasks. The six levels of learning are remembering, understanding, applying, analyzing, evaluating, and creating. They represent a continuum of increasing cognitive complexity 
ranging from concrete (factual) to abstract (metacognitive) and are helpful in developing the intended learning outcomes. At each cognitive level below, the learning outcome is identified along with a list of measurable action verbs which can be used in question stems to assess if learners have accomplished the intended learning outcome are delineated. Some activities that were useful in engaging learners in active learning at the six levels of learning are also outlined.

Cognitive domain: Remember: This is the most basic level of the cognitive domain. At this level, the learning outcomes involve simply recalling and recognizing previously learnt material from long term memory.

Table 1. Cognitive domain: Remember

\begin{tabular}{|l|l|l|l|}
\hline Learning Outcome & \multicolumn{1}{|c|}{$\begin{array}{c}\text { Some recommended } \\
\text { Learning Activities }\end{array}$} & $\begin{array}{l}\text { Measurable Action } \\
\text { verbs }\end{array}$ & $\begin{array}{l}\text { Some Useful Question stems } \\
\text { for assessment tasks }\end{array}$ \\
\hline $\begin{array}{l}\text { Ability to retrieve } \\
\text { information i.e. defini- } \\
\text { tions, recall basic } \\
\text { concepts, identify } \\
\text { terms. }\end{array}$ & $\begin{array}{l}\text { Match words with their } \\
\text { definitions. } \\
\text { List the steps of an activity. } \\
\text { Select the appropriate vo- } \\
\text { cabulary from a list of op- } \\
\text { tions Identify the correct } \\
\text { term } \\
\text { Discuss the word definitions } \\
\text { with your partner. }\end{array}$ & $\begin{array}{l}\text { define, describe, } \\
\text { label, locate, match, } \\
\text { list, memorize, } \\
\text { recognize, name, } \\
\text { state, identify, or } \\
\text { repeat, recall, select }\end{array}$ & $\begin{array}{l}\text { Can you identify the .....? } \\
\text { Name the ...... } \\
\text { Match the...... } \\
\text { Find the meaning of...... } \\
\text { What is the name of..... } \\
\text { List the adjectives in the.. }\end{array}$ \\
\hline
\end{tabular}

Cognitive domain: Understand: At this level, learners progress beyond simply retrieving factual information. They develop an understanding of content by organizing, comparing, interpreting, and describing the factual information.

Table 2. Cognitive domain: Understand

\begin{tabular}{|l|l|l|l|}
\hline $\begin{array}{c}\text { Learning Out- } \\
\text { come }\end{array}$ & \multicolumn{1}{|c|}{$\begin{array}{c}\text { Some recommended } \\
\text { Learning Activities }\end{array}$} & $\begin{array}{l}\text { Measurable Action } \\
\text { verbs }\end{array}$ & $\begin{array}{l}\text { Some Useful Question stems } \\
\text { for assessment tasks }\end{array}$ \\
\hline $\begin{array}{l}\text { Ability to understand } \\
\text { information and } \\
\text { explain meaning of } \\
\text { terms, ideas, situation } \\
\text { or process. }\end{array}$ & $\begin{array}{l}\text { Explain the steps of an activi- } \\
\text { ty. } \\
\text { Describe the meaning of } \\
\text { terms using a dictionary. } \\
\text { Give examples. } \\
\text { Select the suitable words for } \\
\text { a cloze exercise. } \\
\text { Classify words according to } \\
\text { word classes } \\
\text { Retell the story in your } \\
\text { words. }\end{array}$ & $\begin{array}{l}\text { Elassify, Discuss } \\
\text { Outline } \\
\text { Illustrate }\end{array}$ & $\begin{array}{l}\text { Explain the definitions } \\
\text { of...? } \\
\text { Outline key words that } \\
\text { illustrate...? } \\
\text { Classify the affixes ... } \\
\text { Finding a specific example or } \\
\text { illustration of..? } \\
\text { Rewrite... in your own words? } \\
\text { Discuss the main idea and } \\
\text { supporting details. } \\
\text { Draw a logical conclusion from } \\
\text { presented information. }\end{array}$ \\
\hline
\end{tabular}

Cognitive domain: Apply: With this level, learners are able to execute and implement the newly gained knowledge in a different situation i.e. using function and content words to construct sentences or solve a problem. 
Table 3. Cognitive domain: Apply

\begin{tabular}{|l|l|l|l|}
\hline Learning Outcome & $\begin{array}{l}\text { Some recommended } \\
\text { Learning Activities }\end{array}$ & Measurable Action verbs & $\begin{array}{l}\text { Some Useful Question } \\
\text { stems for assessment } \\
\text { tasks }\end{array}$ \\
\hline $\begin{array}{l}\text { Ability to use infor- } \\
\text { mation in a new way } \\
\text { i.e. to complete a task } \\
\text { that may be similar in } \\
\text { nature or to solve } \\
\text { problems }\end{array}$ & $\begin{array}{l}\text { Collaborate to modify the } \\
\text { word formations. } \\
\text { Build a word family. } \\
\text { Role play a situation using } \\
\text { prompts. } \\
\text { Think, pair and share to } \\
\text { predict what might happen } \\
\text { next. } \\
\text { Solve vocabulary quizzes } \\
\text { by gamifying learning } \\
\text { Kahoot) } \\
\text { Act a scene from a play...? }\end{array}$ & $\begin{array}{l}\text { Demonstrate, Apply, } \\
\text { Sequence, Change, Solve, } \\
\text { Modify, Determine, Predict }\end{array}$ & $\begin{array}{l}\text { Modify the word forms to } \\
\text { rewrite sentences by retain- } \\
\text { ing original meaning. } \\
\text { Distinguish gerunds from } \\
\text { infinitives in text } \\
\text { Demonstrate how you } \\
\text { would ...use ...collocation } \\
\ldots \text { for...? } \\
\text { Sequence the events in the } \\
\text { correct order } \\
\text { Predict what may happen } \\
\text { when...? } \\
\text { Determine suitable syno- } \\
\text { nyms to complete the } \\
\text { sentences...? }\end{array}$ \\
\hline
\end{tabular}

Cognitive domain: Analyze: In this level, learners' progress beyond knowledge and application into examining and dissecting information into its constituent parts to induce how the parts relate to one another as well as the overall structure or purpose by identifying causes, making inferences and finding evidences to support generalizations. Learners begin utilizing their critical thinking skills. For this reason, analyzing is listed in the upper-half of the six levels of learning in Bloom's taxonomy.

Table 4. Cognitive domain: Analyze

\begin{tabular}{|c|c|c|c|}
\hline Learning Outcome & \begin{tabular}{|c|c} 
Some recommended \\
Learning Activities
\end{tabular} & Measurable Action verbs & $\begin{array}{c}\text { Some Useful Question } \\
\text { stems for assessment tasks }\end{array}$ \\
\hline $\begin{array}{l}\text { Ability to differentiate } \\
\text { parts of information to } \\
\text { understand the rela- } \\
\text { tionship of the parts to } \\
\text { the whole. } \\
\text { i.e. Differentiating } \\
\text { prefixes and suffixes } \\
\text { to analyze how affixes } \\
\text { change meanings (this } \\
\text { usually requires } \\
\text { learners to use com- } \\
\text { parative and/or } \\
\text { deconstruction skills). }\end{array}$ & $\begin{array}{l}\text { How would you link this } \\
\text { situation with your life } \\
\text { experiences? } \\
\text { Analyze the relevant } \\
\text { events in the text } \\
\text { Review your composition } \\
\text { according to criteria in } \\
\text { rubric? } \\
\text { Model a word family } \\
\text { Compare/contrast your } \\
\text { answer with your part- } \\
\text { ner's answer? } \\
\text { Gamifying of learning } \\
\text { (Quizlet) }\end{array}$ & $\begin{array}{l}\text { Differentiate, Distin- } \\
\text { guish, Classify, Exam- } \\
\text { ine, Model, Com- } \\
\text { pare/Contrast, Analyze, } \\
\text { Subdivide, Separate, Link, } \\
\text { Relate }\end{array}$ & $\begin{array}{l}\text { Classify...content and } \\
\text { function words } \\
\text { Analyze the causes/effects } \\
\text { of..? } \\
\text { Construct a flow chart to } \\
\text { display the sequence of } \\
\text { events using content words? } \\
\text { Differentiate the prefixes } \\
\text { and suffixes in two columns }\end{array}$ \\
\hline
\end{tabular}

Cognitive domain: Evaluate: At this level, learners are able to assess information and draw a conclusion by using a definite criteria and rationale as basis. It involves checking, critiquing and decision-making and the actions display ability to reflect at the pros and cons in order to make judgments about the value of information. Evaluation is a complex mental process as it involves. presenting and defending opinions by making judgments regarding the quality of work based on a set of criteria and ra- 
tionale. Raya, Lamb and Vieira (2007) emphasize on "the conceptual link between autonomy and rationality" (p. 43) and claim that "the competence to think critically is coextensive with the notions of autonomy and self-sufficiency" (p. 43).

Table 5. Cognitive domain: Evaluate

\begin{tabular}{|c|c|c|c|}
\hline Learning Outcome & $\begin{array}{l}\text { Some recommended } \\
\text { Learning Activities }\end{array}$ & $\begin{array}{c}\text { Measurable Action } \\
\text { verbs }\end{array}$ & $\begin{array}{c}\text { Some Useful Question } \\
\text { stems for assessment } \\
\text { tasks }\end{array}$ \\
\hline $\begin{array}{l}\text { Ability to judge infor- } \\
\text { mation using specific } \\
\text { criteria and rationale as } \\
\text { basis } \\
\text { i.e. peer editing as- } \\
\text { signed task using a } \\
\text { checklist or rubric (this } \\
\text { usually requires stu- } \\
\text { dents to critically, } \\
\text { examine specific parts } \\
\text { of information to } \\
\text { interpret the underly- } \\
\text { ing idea). }\end{array}$ & $\begin{array}{l}\text { Summarize information. } \\
\text { Critique information. Justify } \\
\text { your position } \\
\text { Propose how the story would } \\
\text { be different if it..... . } \\
\text { Recommend a title to the ... } \\
\text { Justify why you chose the } \\
\text { title? } \\
\text { Pair with your partner to } \\
\text { discuss what you believe are } \\
\text { the most significant caus- } \\
\text { es/effects of .... Give a } \\
\text { presentation of your view- } \\
\text { points. } \\
\text { Debate the pros and cons } \\
\text { of...using domain specific } \\
\text { vocabulary }\end{array}$ & $\begin{array}{l}\text { Evaluate, Compare } \\
\text { Contrast, Criticize, } \\
\text { Select, Support, Defend, } \\
\text { Justify. Recommend, } \\
\text { Summarize, Debate, } \\
\text { Judge, Conclude, Inter- } \\
\text { pret }\end{array}$ & $\begin{array}{l}\text { Do you agree that...? } \\
\text { Defend your viewpoint } \\
\text { Evaluate what would } \\
\text { happen if...? } \\
\text { Summarize your views } \\
\text { on.... } \\
\text { Why do you recommend } \\
\ldots \text {.. as a better option? } \\
\text { Justify your position } \\
\text { Differentiate facts from } \\
\text { opinions } \\
\text { Interpret data from visual } \\
\text { graphic representations } \\
\text { Make inferences using } \\
\text { context clues }\end{array}$ \\
\hline
\end{tabular}

Cognitive domain: Create: Creating is esteemed as the highest level of cognitive thinking in Bloom's Taxonomy. In this level, learners are able to compile information together to form a new coherent or functional whole by reorganizing elements into a new pattern or structure through generating, planning, or producing alternative solutions. Little (1991) describes autonomy as a capacity "for detachment, critical reflection, decision-making, and independent action" (p. 4).

Table 6. Cognitive domain: Create

\begin{tabular}{|l|l|l|l|}
\hline Learning Outcome & $\begin{array}{l}\text { Some recommended } \\
\text { Learning Activities }\end{array}$ & $\begin{array}{c}\text { Measurable Action } \\
\text { verbs }\end{array}$ & $\begin{array}{l}\text { Some Useful Question stems } \\
\text { for assessment tasks }\end{array}$ \\
\hline $\begin{array}{l}\text { Ability to create a } \\
\text { new product or to } \\
\text { generate new ide- } \\
\text { as.i.e. design a poster } \\
\text { to raise awareness on } \\
\text { an issue }\end{array}$ & $\begin{array}{l}\text { Justify whether.........is } \\
\text { good or bad. } \\
\text { Defend your opinion. } \\
\text { Develop a role play } \\
\text { Formulate alternate solu- } \\
\text { tions for an issue } \\
\text { Construct a cause /effect } \\
\text { flow chart of events }\end{array}$ & $\begin{array}{l}\text { Compose, Generate, } \\
\text { Revise, Organize, } \\
\text { Design, Justify, } \\
\text { Develop, Role-play, } \\
\text { Formulate, Summarize, } \\
\text { Incorporate }\end{array}$ & $\begin{array}{l}\text { Design a PPT presentation on a } \\
\text { proposed plan } \\
\text { What further questions/issues } \\
\text { can be studied to look at the } \\
\text { tives? } \\
\text { Compose an opinion paragraph } \\
\text { justifying your position on....... } \\
\text { Summarize the information. } \\
\text { Use compound nouns to express } \\
\text { your ideas. }\end{array}$ \\
\hline
\end{tabular}




\section{$3 \quad$ Methodology}

The study utilized a quantitative method to examine if there was a statistically remarkable differentiation between students' accomplishments in an exam before and after applying student centered approaches.

Sample: The sample for this study consisted of 39 students (nine males and thirty females) who were studying course entitled English for Business in Department of English Language \& Literature, College of Arts, during the academic year 2018-19 at University of Bahrain. It is a credit bearing level 2 course that emphasizes on vocabulary building, reading skills, grammar, and writing for business correspondences. The course aims to enhance learners' language skills to enable them to communicate constructively in various business contexts.

Instrument: The design selected for the study was Paired sample t-test. Pre- and post-tests were administered as assessment tools for measuring the effectiveness of students' performances before and after implementing the learner centred instructional approach using Blooms taxonomy. The pre-test was given on March 20 and the post-test was given on April 24. A variety of questions types and many elicitation techniques were used to assess students. The test comprised of multiple-choice questions. Each MCQ question stem had four listed responses: three distractors and one correct response. The Gap-filling questions required completing sentences by filling the gaps. Transformation questions requiring rewriting sentences using appropriate word forms so that they retained the same meaning as the original sentences. Matching questions requiring linking words to their definitions, higher order questions included six question types: inference questions requiring inductive or deductive reasoning, comparison questions requiring identifying synonyms and antonyms, context clues questions requiring using text structure to comprehend the meaning from context defining content words, word building questions requiring prefixes or suffixes, and finally logical reasoning questions requiring choosing the appropriate word from the given alternatives of domain specific vocabulary. The test consisting of twentyfive questions assessed students' proficiency in language learning by gauging their competency in understanding, building and using active and passive vocabulary related to academic course material. The pre- and post- test scores obtained from students were compiled and the scores were entered into SPSS. The data was collected, tabulated and analyzed. Descriptive statistical using the mean and standard deviation and inferential statistical using paired sample t-test were applied to examine if there is a significant difference between learners' accomplishments on the pretest and post-test scores after the intervention. In addition, the results were elaborated though bar graphs for better understanding.

\section{$4 \quad$ Result}

With reference to the experimental evaluation analysis of quantitative data, the findings show that implementing the organizational hierarchy of Bloom's taxonomy as learning approach for enhancing student centered vocabulary learning Bloom's was 
found effective on students' retention as it had a statistically significant positive impact on students as they boosted students' accomplishment in vocabulary acquisition, fostered retention of newly learnt words and expanded their range of active vocabulary and built learner autonomy, $\mathrm{t}(36)=3.16, \mathrm{P}<0.05$. The scores mean indicate that there is a significant difference between the performance of students on the pretest $($ mean $=15.53, \mathrm{SD}=5.141)$ and posttest $($ mean $=18.28, \mathrm{SD}=3.881)$ groups on pretest.

Table 7. Descriptive and Inferential Analysis of Academic Achievement

\begin{tabular}{|l|l|l|l|l|l|}
\hline \multicolumn{1}{|c|}{ Groups } & \multicolumn{1}{|c|}{$\mathbf{N}$} & \multicolumn{1}{c|}{ Mean } & \multicolumn{1}{c|}{ St. Dev. } & $\boldsymbol{t}$-value & $\boldsymbol{p}$-value \\
\hline Pretest & 36 & 15.53 & 5.141 & \multirow{2}{*}{3.16} & 0.003 \\
Posttest & 36 & 18.28 & 3.881 & & \\
\hline
\end{tabular}

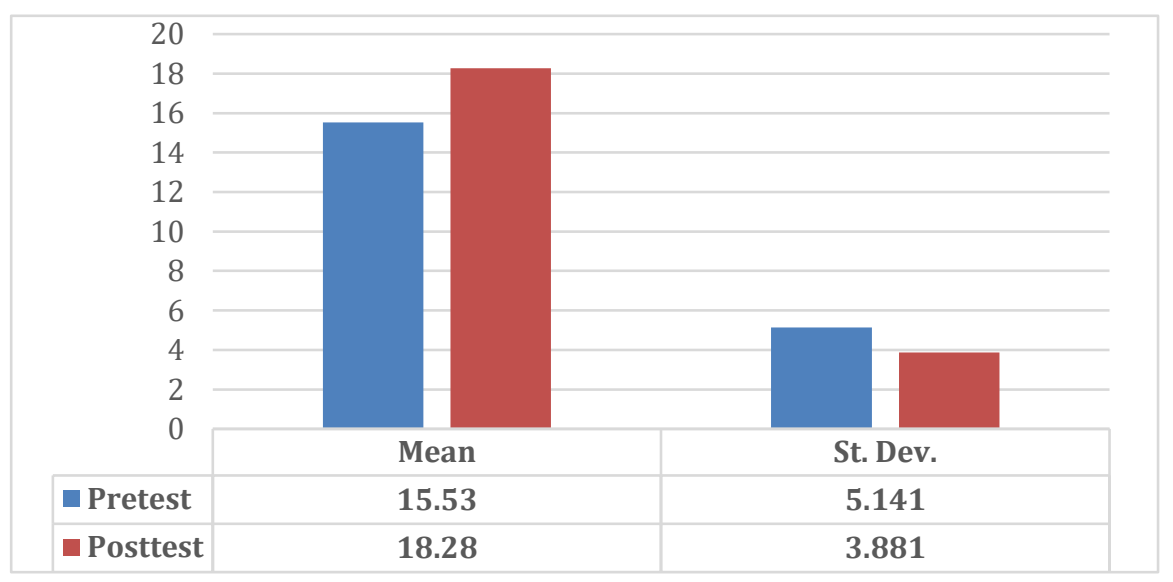

Fig. 1. Showing the Mean \& Standard Deviation of the Performance of Pretest and Posttest

The analysis makes clear that using the cognitive domains of Bloom's taxonomy in active learning activities during classroom teaching appreciably foster active engagement of students. The study indicates that the most relevant cognitive levels in Bloom's taxonomy are creation, evaluation and knowledge while the most applicable levels are knowledge, understand, analysis and application as a lot of emphasis is allocated to remembering and recalling the knowledge. Finally, implementation of the vocabulary learning strategies not only helped in the retention of the vocabulary but they also instilled within students a sense of contentment and pride as they could use precise terminology to express their real-life experiences. Vocabulary is a strong indicator of students' successes (Baker, Simmons, and Kame'enui, 1997).

\section{Discussion}

The aim of the study was to explore the effect of Bloom's learning taxonomy on students' academic achievement and retention and transfer of vocabulary knowledge of English at higher education level. The authors relied on Bloom's taxonomy as a 
guide when writing measurable student learning outcomes. While utilizing active learning strategies in teaching learning process, a list of cognitive action verbs were aligned according to the six cognitive hierarchical levels. Furthermore, Bloom's taxonomy was used in designing a checklist for assessment tasks. It was handy to keep a list of question prompts relating to the various levels of Bloom's Taxonomy in an endeavor to encourage higher-order thinking in learners. It helped in ensuring that students had attained the learning objectives. Active engagement in tasks led to durable learning, and fostered vocabulary accomplishment through expansion of expressive vocabulary as students continually integrated new knowledge into existing knowledge. Findings suggest that fostering higher order thinking contributes substantially to student learning. The results of this study are in line with another educational research on student achievement (Klenowski, 1995; Geven and Santa, 2010). Zwiers et al. (2014) suggest, students comprehend academic content better when engaged in higher order learning activities. Findings suggest that fostering higher order thinking yield positive results. The findings also revealed that promoting higher order thinking skills, as hierarchically organized by Bloom's taxonomy, increases both academic achievement and English proficiency.

\section{Conclusion}

This study presents corroborating evidence that Bloom's learning approach has a positive effect on students' academic achievement and retention of vocabulary knowledge in English. Furthermore, Bloom's learning approach was found effective and useful at all levels of cognitive domain. Furthermore, student centred approaches build collaborative and communicative classrooms (Brown, 2003; Nation, 1993) which fostered opportunities to learn authentic language that is applied in the real world to accomplish tasks. The classroom environment emphasized on interaction, conversation, and vocabulary usage, rather than on learning about the language. Students were actively engaged in the tasks that required them to progress beyond the "read, recognize, and remember" aspects of language. Active participation through the use of higher-order thinking skills, assisted learners in retaining language content for a longer duration and extensive practice helped them in internalizing the newly gained knowledge and transfer it in unfamiliar situations by generating useful language. Gradually, students progressed through the stages of analysis, evaluation and creation towards building learner autonomy. Hence infusion of student centred approaches to vocabulary building is suggested as they will bring sustainable education. Oxford (1990) asserts that appropriate use of strategies "enable students to take responsibility for their own learning by enhancing learner autonomy, independence, and self-direction" (p.10).

\section{$7 \quad$ Limitations of the Study}

One of the limitations of the study was the comparatively small sample size used for the purpose. Thirty-nine students enrolled for the course entitled English for Busi- 
ness in Department of English Language \& Literature, College of Arts, at University of Bahrain during the academic year 2018-19, participated in this study. A larger sample size would have ensured a representative distribution of students' development of vocabulary building using student centred approaches.

\section{$8 \quad$ Recommendation}

Based on findings and conclusion, it is recommended that educators should adopt Bloom's learning approach for teaching English vocabulary as it is effective and useful One of the key objectives of education is to develop students' intellectual ability or thinking capacity. A further research on vocabulary accomplishment and development, especially in English as a Second Language (ESL) context, can be conducted by comparing students from different faculties in University of Bahrain. It is recommended, at a later stage, to research the progress of students who participated in this study, to attain a clearer perception into their ongoing progression in using expressive vocabulary skillfully and to which extend, do their utilization, boost their language comprehensibility as they progress to higher levels of education. A reflection of these determinants can be of much significance for future researches on vocabulary building and retention strategies.

\section{$9 \quad$ References}

[1] Baker, S., and Kame'enui. (1997). Vocabulary acquisition: Research bases. In Simmons, D. C. \& Kame'enui, E. J. (Eds.), What reading research tells us about children with diverse learning needs: Bases and basics. Mahwah, NJ: Erlbaum. https://doi.org/10.4324/97814106 $\underline{03579}$

[2] Bloom, B. S. (1956). Taxonomy of educational objectives: The classification of educational goals. Handbook I. Cognitive Domain. New York: Longman.

[3] Brown, K. L. (2003). From teacher-centered to learner centered curriculum: Improving learning in diverse classrooms. Education, 124(1), 49-54.

[4] Case, R. (2013). The unfortunate consequences of Bloom's taxonomy. Social Education, 77(4), 196-200.

[5] Fernandes, S., Flores, M., and Lima, R. (2012). Students' views of assessment in project-led engineering education: Findings from a case study in Portugal. Assessment \& Evaluation in Higher Education, 37(2), 163-178. https://doi.org/10.1080/02602938.2010.515015

[6] Geven, K., and Santa, R. (2010). Student Centred Learning: Survey Analysis Time for Student Centred Learning. Bucharest: European Students Union. https://doi.org/10.1007/97894-007-3937-6_9

[7] Geven, K., and Santa, R. (2010). Student Centred Learning: Survey Analysis Time for Student Centred Learning. Bucharest: European Students Union. http://www.esib.org/index. php/Publications.

[8] Grabinger, R. S. and Duffield, A. J. (1996). Problem-based learning as a rich environment for active learning. Paper presented at the Annual Convention of the American Research Association, New York, NY. 
[9] Grabinger, R. S. R. Dunlap, J. C. (1994). Implementing rich environments for active learning: A case study. Paper presented at the Annual Conference of the Association for Communications and Technology, Nashville, TN

[10] Jacobson, T. E., and Mark, B.L. (1995). Teaching in the information age: Active learning techniques to empower students. Reference Librarian, 51(52), 105-20. https://doi.org/10.13 00/j120v24n51 11

[11] Klenowski, V. (1995). Student Self-Evaluation Processes in Student-Centred Teaching and Learning Contexts of Australıa And England, Assessment in Education: Principles, Policy \& Practice; 2(2), 145-163. https://doi.org/10.1080/0969594950020203

[12] Klenowski, V. (1995). Student Self-Evaluation Processes in Student-Centred Teaching and Learning Contexts of Australıa And England, Assessment in Education: Principles, Policy \& Practice; 2(2), 145-163. https://doi.org/10.1080/0969594950020203

[13] Krathwohl, D. R. (2002). A revision of Bloom's taxonomy: An overview. Theory into practice, 41(4), 212-218.

[14] Little, D. (1991). Learner autonomy I: Definitions, issues and problems. Dublin: Authentik.

[15] Maclellan, E. (2008). The Significance of Motivation in Student-centred Learning: A Reflective Case Study. Teaching in Higher Education, 13(4), 411-421. https://doi.org/10.1080/13562510802169764. https://doi.org/10.1080/13562510802169681

[16] Meyers, C., and Jones, T. B. (1993). Promoting active learning. Strategies for the college classroom. California: Jossey-Bass.

[17] Newble, D, \& Cannon, R. A handbook for teachers in universities and colleges. London: Kogan Page, 1995.

[18] O'neill, G., \& Murphy, F. (2010). Guide to taxonomies of learning. UCD Teaching and Learning/Resources

[19] Oxford, R. (1990). Language learning strategies: what every teacher should know. New York: Newbery House. https://doi.org/10.3138/cmlr.47.2.374

[20] Raya, M. J., Lamb, T., \& Vieira, F. (2007). Pedagogy for autonomy in language education in Europe: Towards a famework for learner and teacher development. Dublin: Authentik.

[21] Silberman, M. (1996). Active learning: 101 strategies to teach any subject. Prentice-Hall: Massachusetts.

[22] Tenenbaum, G., S. Naidu, O. Jegede, and J. Austin. (2001). Constructivist pedagogy in conventional on campus and distance learning practice: An exploratory investigation. Learning and Instruction, 11(2), 87-111. https://doi.org/10.1016/s0959-4752(00)00017-7

[23] White, S.C. (1996), Depoliticising Development: The Uses and Abuses of Participation, Development in Practice, 6(1), 6-15. https://doi.org/10.1080/0961452961000157564

[24] Zwiers, J., O'Hara S., \& Pritchard R. (2014). Common Core Standards in diverse classrooms: Essential practices for developing academic language and disciplinary literacy. Portland, ME: Stenhouse Publishers.

\section{Authors}

Preeti Jaiswal is a lecturer and Coordinator at the English Language Centre, University of Bahrain. She is Senior Fellow (SFHEA) of Advance HE, Higher Education Academy, United Kingdom. She is a member of the Unit for Teaching Excellence and Leadership (UTEL) at the University of Bahrain (UoB), and mentor of one of UTEL's faculty development programs, namely the Continuous Professional Development (CPD) program of Advance HE, Higher Education Academy, United Kingdom. She 
has an MA in English literature from Delhi University, India and has completed CELTA and TESOL. She has twenty-three years' experience of teaching ESL, ESP and EAP courses at University level. Since 2011, she has been teaching at University of Bahrain. In May 2004, she received Certificate of Appreciation by Chairman, Department of English, Garyounis University. In June 2018, she received the Teaching Excellence Award and Professional Development award by the Director, English Language Centre, University of Bahrain.

Abdulghani Al-Hattami is an assistant professor at Bahrain Teachers College of University of Bahrain. He also worked as assistant professor at the Deanship of Education Development at the University of Dammam from 2012 to 2015, where he received the Excellence Teaching Award. After completing his Master's degree in English Language Teaching, he was awarded a Fulbright scholarship to complete another master's in research methodology from Loyola University Chicago (2006). He then received teaching and research positions at the University of Pittsburgh, where he earned his doctoral degree in measurement, statistics, and research design (2012). aalhattami@uob.edu.bh

Article submitted 2020-04-15. Resubmitted 2020-05-06. Final acceptance 2020-05-07. Final version published as submitted by the authors. 